\title{
THERMAL PROPERTIES OF INDIAN MUNICIPAL SOLID WASTE OVER THE PAST, PRESENT AND FUTURE YEARS AND ITS EFFECT ON THERMAL WASTE TO ENERGY FACILITIES
}

\author{
Roshni Mary Sebastian and Babu Alappat \\ Department of Civil Engineering, IIT Delhi, New Delhi, India
}

\begin{abstract}
Management of municipal solid waste (MSW) has been a grave issue all over the world. The conventional environment friendly techniques adopted to tackle the matter is turning futile owing to the appalling increase in the waste generation rate. The resultant environmental and health hazards emphasise the need for a more rapid solution. An apt and quick response to India's mounting waste management and energy demand crisesis the promotion and execution of waste to energy technologies. Although the MSW composition and characteristics in the past have been unfavourable for the successful implementation of waste to energy thermal facilities, there have been variations in the waste characteristics of late, in this regard. Inert fraction which constituted almost 50\% of the Indian MSW in the 1970s reduced by 30-40\% by the early 2000s, making energy recovery facilities an economically and environmentally feasible option. The varying trends in MSW characteristics in India are analysed and its implications on the thermal energy recovery techniques are investigated.
\end{abstract}

\section{KEYWORDS}

Municipal Solid Waste, Waste to energy, Incineration, Energy Recovery.

\section{INTRODUCTION}

Urbanization and industrialization have resulted in steady economic growth in most countries including India as obvious from the 5.3\% GDP growth rate in 1985 to as high as $7.4 \%$ in 2014, as per World Bank data[1]. Combined with appalling increase in the population and improved living standards, a significant increase in MSW generationensued. Economic development has a direct impact on the per capita MSW generation[2]. Figure 1 shows the projected steady increase in urban population and the corresponding increase in MSW generated, as reported by Annepu (2012) [3].Figure 2 which has been prepared using World Bank data shows the generation MSW in India as well as other prominent countries. In all the cases, a much higher waste generation rate is expected by 2025. Uninterrupted urban migration has further added to the complexity of MSW generated. Due to the negligence of the concerned authorities, most of the urban centers are overwhelmed by the problems posed by inadequate garbage management. With far higher generation rates anticipated in the future, the waste disposal techniques adopted in India now are abysmal. The conventional management techniques adopted include aerobic composting, vermicomposting, biomethanation and landfilling, most of which have high land requirements. With population explosion and urban migration on the rise, land has become a scarce resource, making it inadequate to manage and dispose the generated MSW. In contrast to unscientific disposal of wastes in random and remote locations, the need of the hour is a prompt and well devised technique to handle the huge quantities of MSW generated per day. 


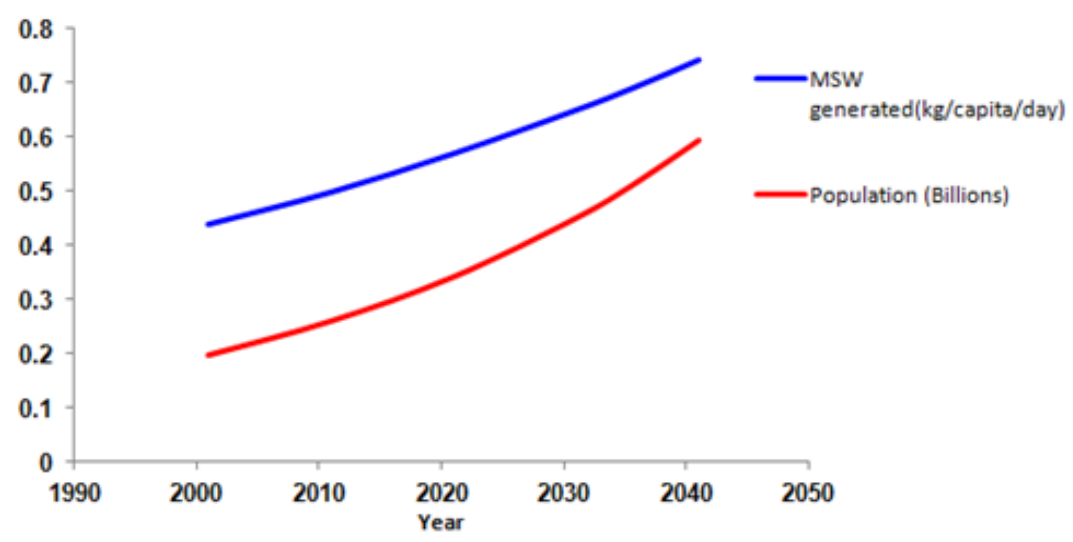

Figure 1: Variation in the quantity of MSW generated and the population in urban India projected to 2041[3]

Collection and segregation of wastes are integral parts of an ideal solid waste management system. Community bin collection system was widely used until recently, when the need for door to door collection system was realized. Furthermore, open collection points pose grave environmental and health hazards. The MSW (Management and Handling) Rules, 2000 emphasises the setting up of containers for waste collection based on the waste generation potential of the local population.

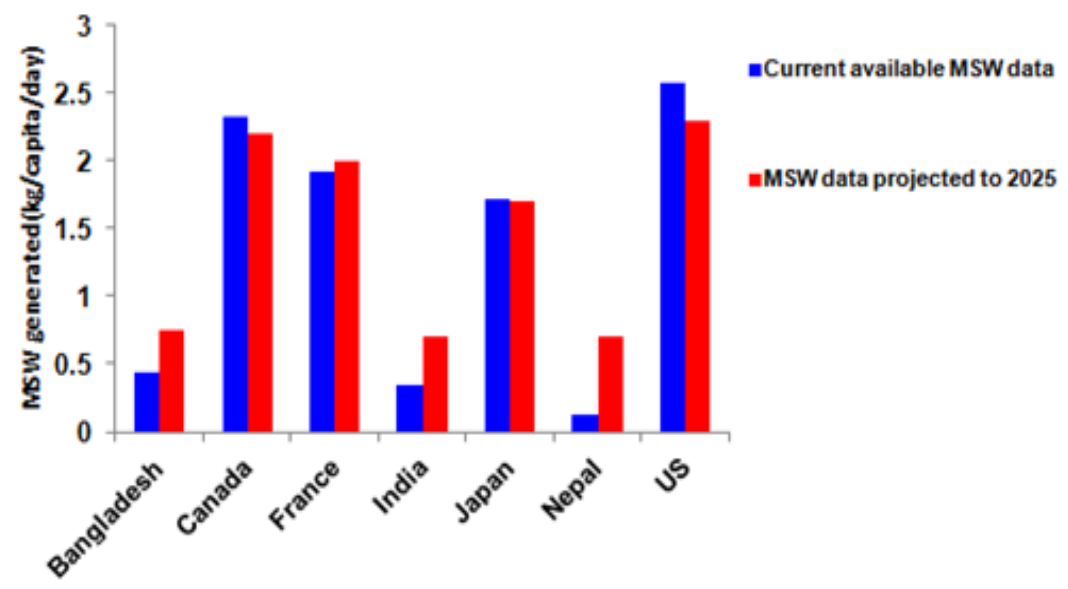

Figure 2: Per capita MSW generation data for prominent countries

Figure 3 shows the wide variations in the quantities of MSW generated, collected and treated as per Central Pollution Control Board (CPCB) statistics last updated in 2012. The collection and segregation of MSW at the source still continue to be a matter of concern and house-to-house collection is yet to gain momentum in most of the cities. In spite of the government initiatives like MSW(Management and Handling) Rules, 2000and the inclusion of NGOs and private agencies to assist in collection, segregation and transport operations, collection efficiency of MSW in Indian cities continues to be on an average of only about $72 \%[2,3,5]$. Ensuring proper segregation at the source is instrumental in determining the efficiency of various MSW management practices. 


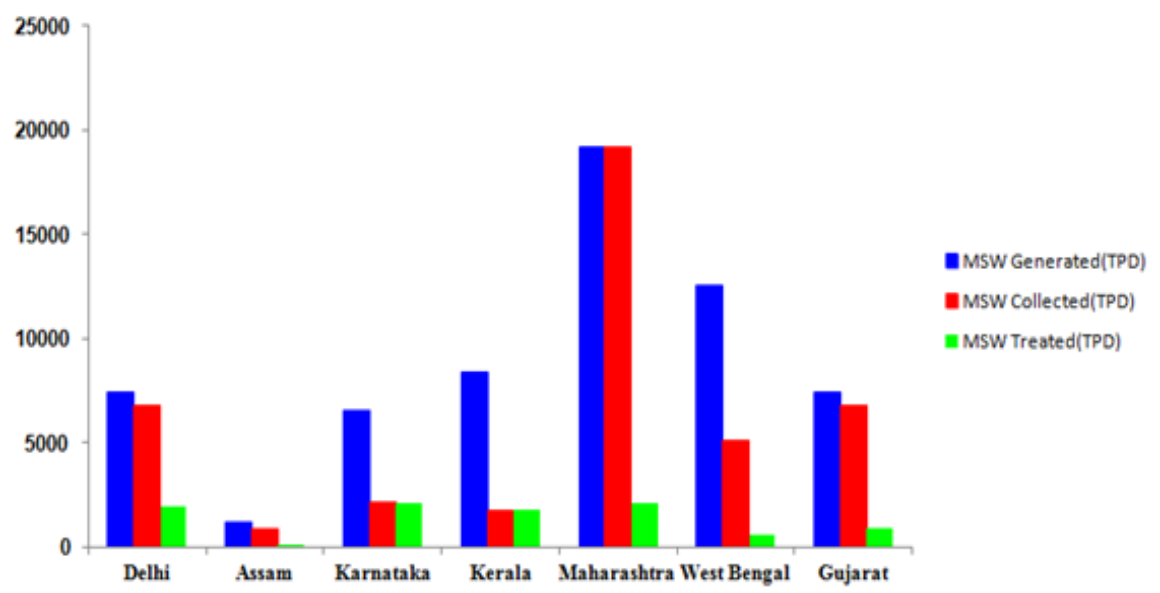

Figure 3: Quantities of MSW generated, collected and treated [6]

In spite of thehuge quantities of MSW generated, especially in the metros, the characteristics of the MSW have been varying slightly in favour of thermal disposal techniques like incineration. The more developed and urbanized the country is, the more is the paper and plastic content of the MSW. In India, paper which constituted about 3\% of the MSW in the 1970s rose to about 8-9\% by 2005 . Also plastic which was hardly $1 \%$ of the MSW composition in 1970 s turned to be approximately $10 \%$ of MSW by 2005[2]. Figure 4 shows the paper, plastic and organic fraction of MSW in developed and developing countries. While developed nations like US and France have high paper and plastic fraction, developing countries like India have high organic content, and hence low calorific value.

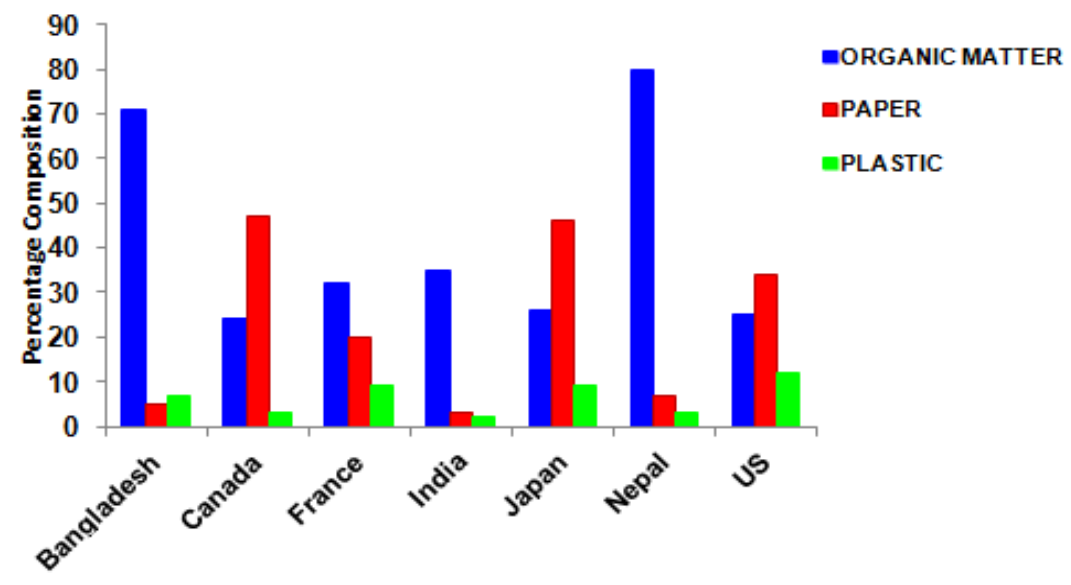

Figure 4: MSW composition in different countries

High inerts fraction and moisture content and consequently the low calorific value of MSW had made thermal treatment techniques for MSW management least preferable in India, until recently.The social stigma to the thermal treatment facilities and the Not In My Backyard (NIMBY) syndrome of the public has further deterred the widespread use of thermal treatment facilities.

Increasing population and the living standards bring in yet another hurdle of enormous energy demand. It is in this context that the thermal treatment facilities offer yet another boon besides rapid MSW disposal. With increasing heat content of the generated MSW, it is possible to recover 
a part, if not full of the energy and use it to satisfy the increasing energy demands.This paper primarily aims at analyzing the variation in the composition of MSW through the years and consequently their heat contents and how it has affected the various treatment techniques.

\section{WASTE GENERATION AND CHARACTERISTICS: A TIMELINE}

As mentioned earlier, India has witnessed an almost steady economic growth, and an overly sturdy growth in population. India has been continuously one of the ten fastest growing medium large countries.

Census 2011 records 5000 towns in India and more than $27.8 \%$ of the population resided in urban areas. With migration rates increasing every year, the current value is expected to be alarmingly high. With simultaneous increase in GDP and population, a subsequent increase in MSW generation was observed. While the quantity increased from 6 to 48 million tons during 1947 to 1996, at $4.25 \%$ growth annually, it is estimated to reach a disturbing value of 300 million tons by 2047[6]. From Figure 1, it can be observed that India whose current per capita generation rate is $0.34 \mathrm{~kg} / \mathrm{capita} /$ day is expected to have an even higher rate of $0.70 \mathrm{~kg} /$ capita/day by $2025[1]$.

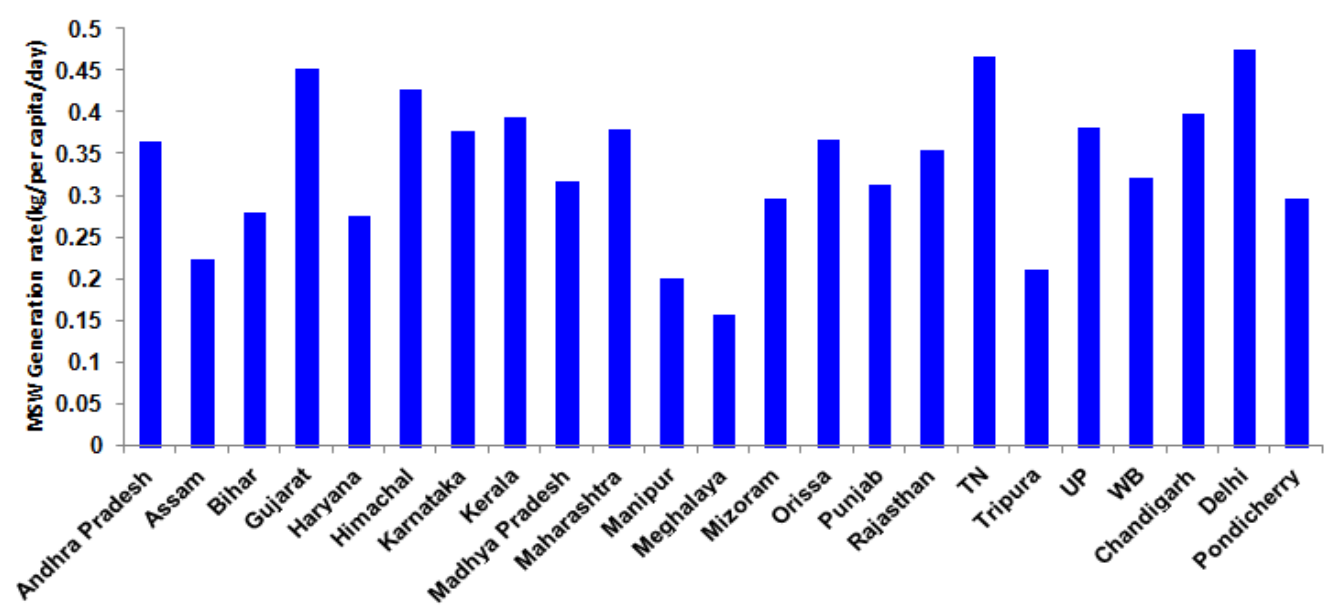

Figure 5: Per capita generation of MSW in various Indian states

Figure 5 shows the per capita MSW generation rates in different states, of which Delhi, Gujarat and Tamil Nadu have comparatively higher rates. The data for preparing the same has been obtained from Status of MSW Generation, collections, treatment and disposal in class- I cities[3,4].

Apart from the huge amount of MSW generated, there were also wide fluctuations in the MSW characteristics. The composition of MSW depended on a multitude of factors like food habits, living standards and lifestyle, climate, culture etc.From Figure 4(prepared from World Bank data), it is evident that organic fraction of MSW is higher in lower middle income countries like India, Bangladesh and Nepal, while paper and plastic constitute a major fraction of high income countries like US and Canada, giving high heat content to their MSW. However, Indian MSW has undergone significant compositional changes over the years. Figure 6 shows the variation in combustibles, non- combustibles and compostables in MSW generated in Delhi from 1971 and projected to $2024[2,5,8,9]$. While the compostable fraction showed marginal decrease, noncombustibles and combustible fraction showed considerable variation in projected values, with former reducing and latter increasing significantly. 
Civil Engineering and Urban Planning: An International Journal (CiVEJ) Vol.3, No.2, June 2016

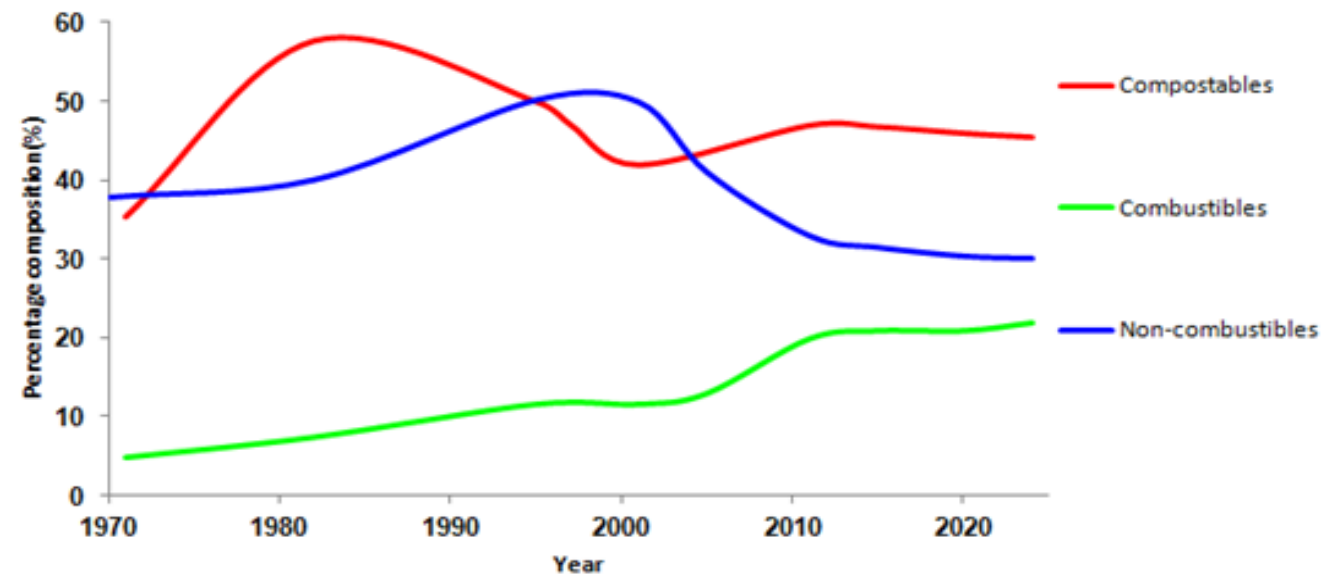

Figure 6: Composition of MSW of Delhi city from 1971 projected till 2024

Manufacture and consumption of plastic have undergone an astounding increase over the last 20 years. Despite a recycling rate of 40-80\%, plastic composition in Indian MSW has increased by $92.4 \%$ in the given time period. Booming literacy rates and enhanced packaging and other uses augmented the content of paper in MSW by almost 50\%. At the same time, inert components in Indian MSW which constituted $49.2 \%$ in 1970 , reduced to $25.16 \%$ by 2005 , and the organic fraction, which was $41.3 \%$ decreased marginally to $40 \%$ by 2005 , on discarded basis[2].

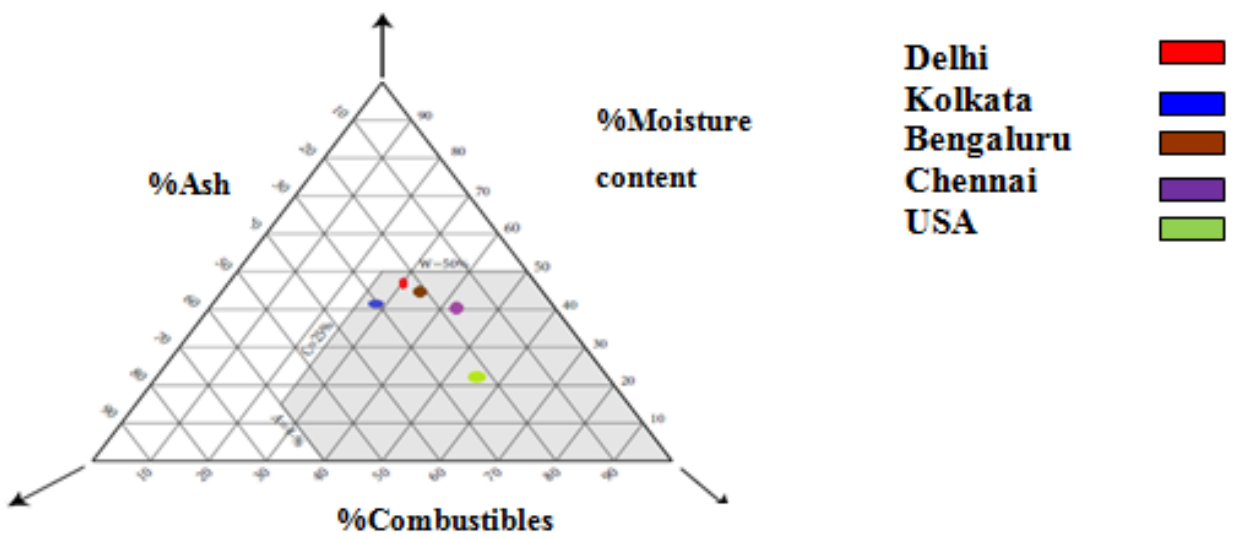

Figure 7: Tanner Diagram

Figure 7prepared using data given by Saini et al., (2012)[9]shows the Tanner diagram, which depicts the combustibility of a particular MSW sample. It can be observed that MSW generated at prominent metros like Delhi, Bengaluru and Chennai now lies in the combustible region shaded in the figure. This can be attributed to the reduced fraction of inerts and moisture content in the MSW. 


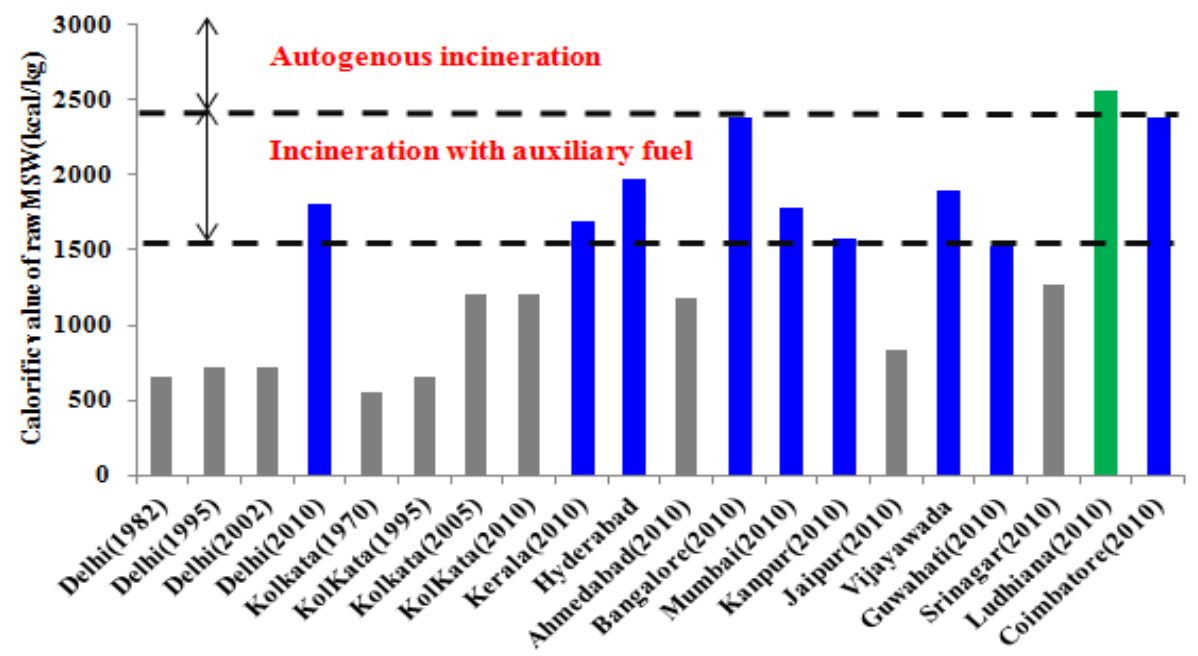

Figure 8: Calorific values of MSW generated in different states

Furthermore, analyzing the calorific valuesof raw MSW from various cities(Figure 8), it was observed that Delhi, Hyderabad, Bengaluru and Coimbatore have high values, above $1500 \mathrm{kcal} / \mathrm{kg}$ while Ludhiana has a calorific value above $2400 \mathrm{kcal} / \mathrm{kg}$ [5-9]. This makes the MSW generated in these cities amenable to thermal treatment techniques like incineration.

\section{CONVENTIONAL MANAGEMENT OPTIONS}

MSW management has always been a headache, especially for developing economies. In India, with high urbanization and population growth, this poses an acute problem. With MSW generation more than 8282.6 tons per day for a metro city like Delhi (2009)[8], conventional management options like biomethanation, composting and landfilling become unfeasible. Moreover, land requirement for these techniques makes it all the more difficult to cater to the huge quantities of MSW generated.

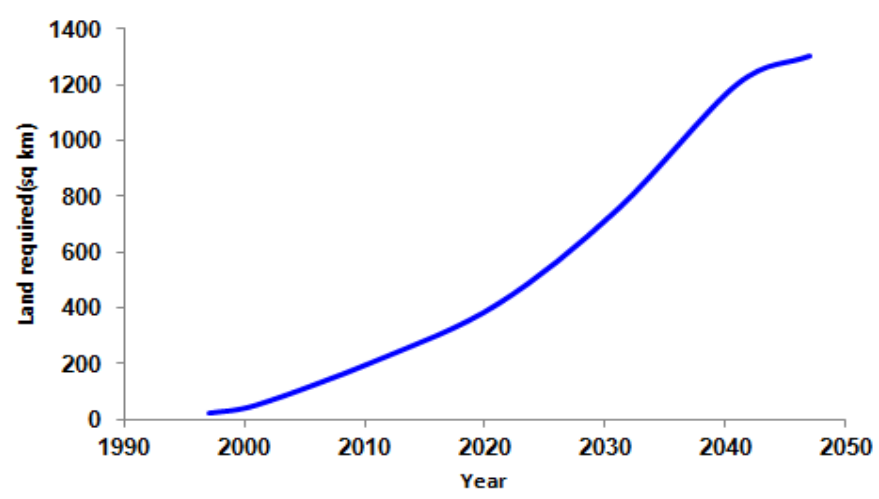

Figure 9: Land required for MSW disposal [13]

Figure 9 shows the increasing demand for land for MSW disposal projected to 2047[13]. In majority of the metropolitan cities, MSW is dumped unscientifically in open dumps resulting in grave environmental issues, like leaching of heavy metals to groundwater and surface water sources, greenhouse gas emissions, flies and odour nuisance, to name a few. With limited land availability $[13,14]$ and high MSW generation rates[2, 8] the future implementation of these techniques are questionable. However, with varying waste characteristics and increasing heat 
Civil Engineering and Urban Planning: An International Journal (CiVEJ) Vol.3, No.2, June 2016

content, [11] andin light of the aforementioned concerns, thermal treatment route, may perhaps prove to be a viable option.

The desirable range of the waste parameters for the implementation of various waste to energy technologies are as tabulated in Table 1. Energy can be recovered in the form of electricity or heat or can be used to obtain a fuel source in the form of Refuse Derived Fuel (RDF), biogas, etc.

Table 1: Desirable range of important waste parameters for technical viability of energy recovery

\begin{tabular}{|c|c|c|c|}
\hline Waste treatment method & Basic principle & $\begin{array}{l}\text { Important waste } \\
\text { parameters }\end{array}$ & $\begin{array}{c}\text { Desirable } \\
\text { Range }\end{array}$ \\
\hline $\begin{array}{c}\text { Thermochemical methods } \\
\text { - Incineration } \\
\text { - Pyrolysis } \\
\text { - Gasification }\end{array}$ & $\begin{array}{c}\text { Decomposition of } \\
\text { organic } \\
\text { matter by action of } \\
\text { heat }\end{array}$ & $\begin{array}{c}\text { Moisture content } \\
\text { Organic/volatile matter } \\
\text { Fixed carbon } \\
\text { Total Inerts } \\
\text { Calorific value (Net } \\
\text { calorific value) }\end{array}$ & $\begin{array}{l}<45 \% \\
>40 \% \\
\\
<15 \% \\
<35 \% \\
>1200 \\
\mathrm{kcal} / \mathrm{kg}\end{array}$ \\
\hline $\begin{array}{l}\text { Biochemical conversion } \\
\bullet \quad \text { Anaerobic } \\
\text { digestion/ } \\
\text { Biomethanisation }\end{array}$ & $\begin{array}{l}\text { Decomposition of } \\
\text { organic } \\
\text { matter by microbial } \\
\text { action }\end{array}$ & $\begin{array}{c}\text { Moisture content } \\
\text { Organic volatile matter } \\
\mathrm{C} / \mathrm{N} \text { ratio }\end{array}$ & $\begin{array}{l}>50 \% \\
>40 \% \\
25-30\end{array}$ \\
\hline
\end{tabular}

Source: The Expert Committee[5].

Energy from MSW can be used as an alternative energy source to cater to high power demands and reduce the pressure on the conventional energy sources. The ministry is actively involved in promoting and funding the setting up of waste to energy facilities.

The major drawback of conventional management techniques like composting is that it is time consuming. To get ripe compost, aerobic windrow composting method requires about 2 to 3 months, whereas vermi-composting takes about 1.5 months. Rotary drum composting requires about 3 weeks, which is a comparatively faster technique. With $0.34 \mathrm{~kg} / \mathrm{capita} / \mathrm{day}$ MSW generation rate and population increasing by the minute, such slow techniques tend to be ineffective. Not only do the waste to energy facilities offer a rapid solution to mounting MSW problem, but also result in significant reduction in waste volumes by almost 60-90\% [15]. Moreover, it helps generate energy from MSW, thus helping to reduce the dependence on fossil fuels and eventually reducing the green house gas emissions.

\section{THERMAL TREATMENT TECHNIQUES: INCINERATION}

In spite of the various thermal treatment options available, incineration is the most widely used technique. Incineration is a controlled and complete combustion of wastes, at high temperatures ranging from $850^{\circ} \mathrm{C}$ to as high as $1200^{\circ} \mathrm{C}$, resulting in reduction in volume by about $80-90 \%$ and destruction of toxic and hazardous matter.Being highly exothermic, the process releases large quantities of heat which can be used for production of steam, heating water and electricity. As per generally followed norms, MSW can be incinerated autogenously if its calorific value is above $2400 \mathrm{kcal} / \mathrm{kg}$; if it is between $1500-2400 \mathrm{kcal} / \mathrm{kg}$, incineration is possible with the aid of an auxiliary fuel.When the calorific value of the MSW is less than $1200-1500 \mathrm{kcal} / \mathrm{kg}$, incineration route is usually dismissed [9]. Incineration of MSW was not employed much in India, largely due 
to high organic content $(40-60 \%)$, low calorific value $(800-1100 \mathrm{kcal} / \mathrm{kg})$ and high moisture content(40-60\%)[14]. However, with its changing characteristics, incineration might perhaps be a favourable choice for MSW management and energy recovery at present. For instance, calorific value of raw MSW generated in Delhi increased from a humble value of $661 \mathrm{kcal} / \mathrm{kg}$ in 1982 to around $2000 \mathrm{kcal} / \mathrm{kg}$ in the year $2010[7,8,15]$. It is expected to reach more than $2100 \mathrm{kcal} / \mathrm{kg}$ by 2024.

With economic growth has increased the demand for electricity generation. The installed electricity generation capacity has increased from 66GW in 1991 to $278.734 \mathrm{GW}$ in 2015 [1619],Ministry of New and Renewable Energy (MNRE) studies reveal that by 2030, coal and oil will contribute to $51 \%$ and $13 \%$ of the total power generation respectively. However, due to increasing energy demand and depleting fossil fuel deposits, it has become obligatory to consider alternative energy sources. MNRE considers waste to energy as an ideal option to tackle India's energy deficit problems and disclosed that urban MSW has an energy recovery potential of 500MW. Figure 10 prepared using data provided by MNRE shows the energy potential of MSW generated in Indian cities, of which Maharashtra has a high potential of around 250MW.

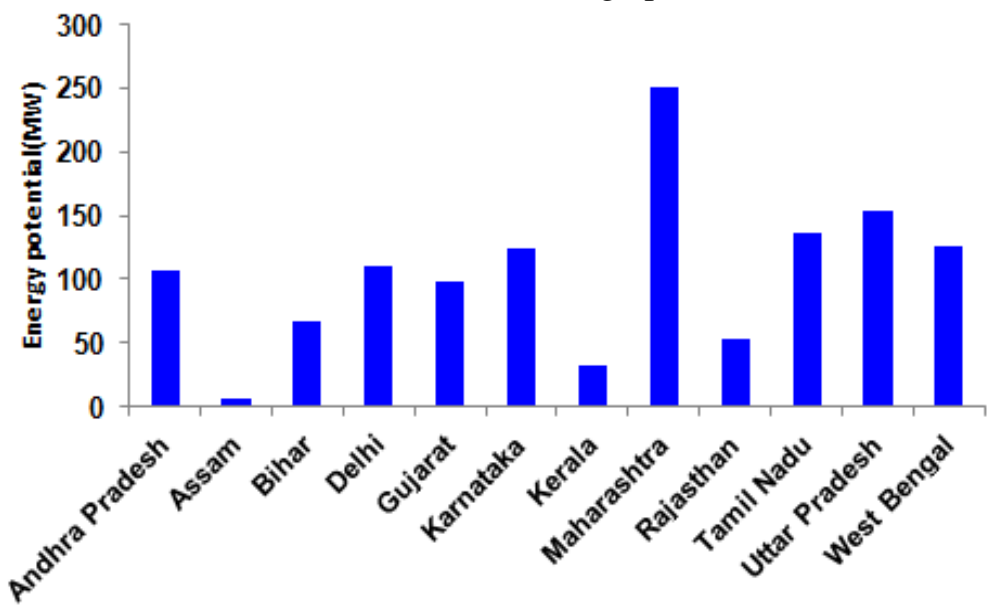

Figure10: Energy potential of MSW generated

In an effort to promote the waste to energy thermal facilities, MNRE provides subsidies and grants under their programme Energy Recovery from Municipal Waste, with an objective of accomplishing international emission standards for waste to energy plants in India.

Despite the various benefits offered by thermal waste to energy facilities, India is yet to have a full fledged and fully operational waste to energy facility. The existing units in India are faced with a number of constraints. India lacks a proper waste segregation stream and this poses a major hindrance to proper functioning of these facilities. Some of the state of the art units like Timarpur plant, Delhi closed down not due to faulty technology, but due to the inconsistencies in the MSW properties. Further, being a new concept, it is yet to gain acceptance and numerous apprehensions associated with this technology add to the problems. The Not In My Backyard attitude of the general public has been adverse to the successful implementation and functioning of thermal waste to energy facilities. Besides, most of the proven technologies need to be imported and financial resources are inadequate with Municipal Corporations and Local Bodies.

In spite of various benefits offered by thermal waste to energy facilities, there are several shortcomings too. Thermal treatment is a cost- intensive process and requires skilled labour during operation and maintenance. Yet another downside to this technology is that if not properly monitored, it can cause air pollution problems due to release of obnoxious gases like $\mathrm{SO}_{\mathrm{X}}, \mathrm{NO}_{\mathrm{X}}$, HF, dioxins, HF etc. Stringent regulations are required to ensure the adherence of the functioning 
Civil Engineering and Urban Planning: An International Journal (CiVEJ) Vol.3, No.2, June 2016

units with the existing emission standards. Table 2 gives the operating and emission standards for incinerators in India. One of the major pitfalls in this regard is the absence of emission standards for dioxins and furans. These are extremely toxic and tend to cause severe cancerous, developmental and reproductive defects. However the standards are being revised and hence will be enforced in near future. Yet another hurdle faced by thermal facilities is the seasonal variation of waste characteristics which can directly affect the calorific values and in turn, the efficiency of the plant.

Table 2: Operating and Emission Standards for Incinerators

\begin{tabular}{|l|c|}
\hline \multicolumn{2}{|c|}{ Operating Standards } \\
\hline Combustion Efficiency & Atleast $99 \%$ \\
\hline Computation of Combustion Efficiency & C.E $=\left(\% \mathrm{CO}_{2} \times 100\right) /\left(\% \mathrm{CO}_{2}+\% \mathrm{CO}\right)$ \\
\hline \multicolumn{2}{|c|}{ Emission Standards } \\
\hline Parameters & Concentration $\mathrm{mg} / \mathrm{Nm}^{3}$ at $\left(12 \% \mathrm{CO}_{2}\right.$ Correction $)$ \\
\hline Particulate matter & $150 \mathrm{mg} / \mathrm{Nm}^{3}$ \\
\hline Nitrogen oxides & $450 \mathrm{mg} / \mathrm{Nm}^{3}$ \\
\hline HCl & $50 \mathrm{mg} / \mathrm{Nm}^{3}$ \\
\hline Minimum Stack Height above the ground & $30 \mathrm{~m}$ \\
\hline Volatile Organic compounds in ash & $\mathrm{Not}>0.01 \%$ \\
\hline
\end{tabular}

\section{CONCLUSION}

Expanding economy and steady population growth have brought the MSW generation in India to an all time high leaving conventional management options ineffective. Poor state of integral operations like collection and segregation further adds to pollution load due to MSW. With higher MSW generation rates anticipated in the future, thermal waste to energy facilities might perhaps prove to be a better management solution. Higher land requirements and slower treatment rates in the conventional route further calls for faster disposal techniques like incineration. Although previously constructed thermal waste to energy had failed owing to the low heat content of the MSW generated, the composition and properties of MSW have been changing ever since. Lower inert and biodegradable fraction and higher paper and plastic content have significantly increased the energy recovery potential of MSW over the years. Besides, the energy recovered could also be used to meet the ever increasing power demands of the country. MNRE has been engaging in promoting waste to energy facilities and estimates to generate 5000 MW from urban MSW by 2020.

\section{REFERENCES}

[1] World Bank, (1999), What a Waste: Solid Waste Management in Asia, Urban Public Sector Unit, The World Bank, Washington, USA.

[2] Kaushal, R. K., Varghese, G. K., Chabukdhara, M., (2012), "Municipal Solid Waste Management in India- Current State and Future Challenges: A Review “, International Journal of Engineering Science and Technology, Vol. 4, No. 4, pp 1473- 1489.

[3] Annepu R.K., (2012), Sustainable Solid Waste Management in India, Department of Earth and Environmental Engineering, Columbia University, pp 1-189.

[4] Kumar, S., Bhattacharyya, J. K., Vaidya, A. N. et al., (2009), “Assessment of the status of municipal solid waste management in metro cities, State Capitals, Class I cities, and Class II Towns in India : An insight", Waste Management, Vol. 29, Issue 2, pp 883- 895.

[5] The Expert Committee, (2000), "Municipal Solid Waste Management Manual”, Ministry of Urban Development Government of India, India. 
Civil Engineering and Urban Planning: An International Journal (CiVEJ) Vol.3, No.2, June 2016

[6] Talyan, V., Dahiya, R.P., Sreekrishnan, T.R., (2008), "State of Municipal Solid Waste Management in Delhi , the Capital of India", Waste Management, Vol. 28, pp 1276-1287.

[7] CPCB, 2004, Status Report on Municipal Solid Waste Management, Ministry of Environment and Forests, New Delhi, India.

[8] Vivekananda B., Nema A.K., (2014), "Forecasting of Solid Waste Quantity and Composition: A Multilinear Regression and System Dynamics Approach”, International Journal of Environment and Waste Management, Vol. 13, Issue 2, pp 179- 198.

[9] Saini S., Rao P., Patil Y., (2012), "City based analysis of MSW to Energy Generation in India, Calculation of State-wise Potential and Tariff Comparison with EU", Procedia - Social and Behavioral Sciences, 37, $407-416$.

[10] Jain, P., Handa, K., Paul A., (2014), "Studies on Waste-to-Energy Technologies in India \& a detailed study of Waste-to-Energy Plants in Delhi”, International Journal of Advanced Research, Vol. 2, Issue 1, pp. 109-116.

[11] World Bank, (1999), Municipal Solid Waste Incineration, The World Bank, Washington DC., USA.

[12] Aswani, S., (2012), "Waste to Energy in India", Energetica India.

[13] Singh, R. P., Tyagi, V. V., Allen T. et al.,(2011), An Overview for Exploring the Possibilities of Energy Generation from Municipal Solid Waste ( MSW ) in Indian Scenario, Renewable and Sustainable Energy Reviews, Vol. 15, Issue 9, pp 4797- 4808.

[14] Sharholy, M., Ahmad, K. et al., (2008), "Municipal Solid Waste Management in Indian Cities - A Review", Waste Management, Vol. 28, pp 459-167.

[15] CPHEEO, (2000), "Manual on Municipal Solid Waste Management", Ministry of Urban Development, New Delhi, India.

[16] Dube, R., Nandan, V., Dua, S., (2014)," Waste incineration for urban India: valuable contribution to sustainable MSWM or inappropriate high-tech solution affecting livelihoods and public health?", International Journal of Environmental Technology and Management, Vol.17, No. 2-4, pp 199-214.

[17] Sastry D.B.S.S.R., "Composition of Municipal Solid Waste- Need for Thermal Treatment in Present Indian Context", Ramky Energy \& Environment Ltd.

[18] Central Statistics Office, (2015), Energy Statistics 2015, Ministry of Statistics and Programme Implementation, New Delhi, India.

[19] www.mnre.gov.in

\section{AUTHORS}

Roshni Mary Sebastian holds a B.Tech (in Civil Engineering) from University of Kerala and M.Tech (in Environmental Engineering) from NIT, Surat. She is currently pursuing her PhD in Environmental Engineering from IIT, Delhi. She has also served as an intern at APC Division, NEERI Nagpur.



Dr. Babu Alappat holds a B.Tech (in Civil Engineering) from University of Calicut, M.Tech (in Environmental Engineering) from University of Kerala, Ph.D (in Environmental Engineering) from IIT Bombay and a Postdoc from Ecole Des Mines De Nantes, France. Currently, Dr. Alappat is a Professor of Environmental Engineering in IIT Delhi and a Visiting Professor in Ecole Des Mines De Nantes, France. He has got about 18 years of experience in research and teaching in the field of Environmental Engineering. He specialises on Incineration Techniques, Fluidized Bed Reactors and Solid Waste Management. He has published more than 100 research papers in International and National Journals and Conferences. He has guided several $\mathrm{Ph} . \mathrm{D}$ and M.Tech projects. $\mathrm{He}$ is an expert consultant to many Govermental and Non-Govermental organisations like Central Pollution Control Board, Dept of Science and Technology, etc. 